\title{
AXIOLOGICAL ASPECTS OF THE FINANCIAL LAW SYSTEM
}

\author{
Imeda A. Tsindeliani \\ Russian State University of Justice \\ 69, Novocheremushkinskaya str., 117418, Moscow, Russia
}

\begin{abstract}
Legal axiology, as a scientific discipline, allows us to consider both the legal system of the State as a whole, and its individual elements from the point of view of the value foundations that exist in society and in each individual. The consideration of the elements of the State's legal system through value categories allows us to determine the relationship and interdependence of all elements of the legal system. It is especially necessary to note the influence of value categories on the formation of a system of the separate branches of the law, including the financial law of Russia. Value categories have an influence not only on the formation of the elements of the financial law system, but also predetermine their interaction as legal means of regulation of the public finances. The elements of the financial law system, as a branch of law, are the principles of the financial law, the rules of the financial law, and their separate forms of grouping - institutions and sub-sectors of the financial law. The principles of the financial law are the direct legal regulators of public relations in the field of public finance by their nature. Possessing regulatory properties, the principles of the financial law shouldn't be identified with the rules of the financial law, since they are independent legal means of the regulation. The principles of the financial law, on the basis of their regulatory properties, should be considered as elements of a system of the financial law.
\end{abstract}

Key words: legal axiology, financial law, financial law principles, financial law provisions, financial law institutions, budget law, tax law, banking law, emission law, financial control law

\section{Introduction}

The influence of the value category on the legal system of the state and its elements is very significant, and is manifested at each stage of the basic legal categories formation. Axiology is a popular philosophical direction that allows one to consider many phenomena of public life from the point of view of value categories, including the legal system of the state. Axiology is popular, but still a very young and actively developing philosophical direction (Stolovich, 2009:20-31). As a result, there are no uniform approaches to the basic categories, first, value categories. The following def-

(C) Tsindeliani I.A., 2020.

This work is licensed under a Creative Commons Attribution 4.0 International License

https://creativecommons.org/licenses/by/4.0 
inition of value category, given by P.E. Matveev, can be taken as a basis. "A special quality that is associated with objects and subjects, and characterizes their uniqueness, unity, their place in the universal relationship. Moral values, respectively, are defined as special properties of objects and subjects, characterizing their uniqueness, unity, their place in the world from the standpoint of good and evil" (Matveev, 2017:6). Constructive realism is the methodological basis of this definition. With regard to the description of legal phenomena from the point of view of axiology, there are a number of methodological obstacles. Namely, the lack of a uniform approach to understanding law. As a result, there is a different understanding of value and value's meaning for the legal system functioning of the state as a whole and state's individual elements, from the point of view of methodological pluralism. (Vetiutnev, 2013).

There is a problem of the correlation of moral values (that underlie axiological postulates) and law. This problem has existed for many years and has been revealed by the authors from various points of view (Tsintsadze, 2013:251-259). As already mentioned, the value category is important not only for the entire legal system of the state but also for its individual elements, including branches of law. In relation to the axiological aspects of financial law, there are studies, which consider the role of value categories in the regulation of relations in the field of public finance (Tsintsadze, 2014).

According to Evdokimov A.Yu., axiology can be useful in jurisprudence for the applied purposes of resolving a conflict between legal norms, principles. A conflict that arose in a particular case and entailing a legal dispute. Axiology is here as a methodology for resolving a conflict, taking into account a value-based approach to these norms, principles. Namely, a methodology that involves a list of specific criteria for assessing norms, principles in relation to the state of the case. Such a methodology also implies the choice of more valuable (significant) norms, principles. Besides, the ratio (hierarchy) of values is built anew for each case. (Evdokimov, 2013:2-5).

It seems that this approach limits the possibilities of axiology, and its significance in relation to the legal system elements and, in particular, the branches of law. Value categories play an important role not only in conflict resolution in branch or interbranch regulation. The value category plays a much broader role than conflict resolution. The values are developed and affirmed in society and in its various organizational forms. Such values directly affect the formation of legal means for social relations regulation. Legal means as a toolkit (that ensures the streamlining of public relations) is based on certain values. Accordingly, values are the basis on which legal means of regulation are developed and, with an eye on such values, they are implemented.

\section{Chapter I}

The system of public finance law remains a sought-after area of scientific research and the subject of discussions (Mrkývka, 2015). There are the researchers' approaches to the elements (that form the system of financial law branch) and to the very institutionalization of the legal branch (Mrkývka, 2017). According to N.M. Kazantsev, financial law cannot be reduced to a tree structure, in which many different 
hierarchical subsystems can be delineated, having a dendritic (tree-like) form. The latter is not a mono-hierarchical, but a multi-hierarchical system, where a higher institution in one hierarchy turns out to be inferior on the other - by indirect links with other financial law institutions (Kazantsev, 2009; 46-47 pp). It is proposed to consider the institution of the financial jurisdiction of the state as such an institution (Kazantsev, 2009:61). Unfortunately, this was not widely adopted in domestic legal literature. In turn, I. B. Lagutin defines the financial law system as a combination of financial institutions and sub-branches. The financial system itself is defined by him as a set of financial law elements, having its own distinctive features and internal structure, isolated from each other, as well as from other branches of law (Lagutin, 2017:52). Studying the problem of differentiation and integration of the financial law system, E. G. Belikov states that the financial law system consists of the following structural elements:

- general and Special parts,

- sub-branches,

- institutions,

— individual financial and legal norms (Belikov, 2016:44).

Considering the problems of the financial law formation, G.G. Pilikin concludes that the system of financial law is not limited to a structure. A structure, which consists of successively placed interacting basic elements - financial and legal norms (their elements); groups of norms (associations); subinstitutes; institutes; sub-branches. Besides such structure, financial law system also includes a legal understanding of the applicable norms, legal structures. Financial law system reflects the relationship and interaction with the financial system, financial policy, as well as with a number of economic activity factors, and judicial practice (Pilikin, 2018:38). As can be seen, in studies there is a different approach to understanding the financial law system and the constituent elements that form it. L.L. Arzumanova states that the financial institution should be considered the lowest link in the financial law system. Such a judgment is quite controversial (Arzumanova, 2016:7). The institute of law is a subsystem of the branch of law and consists of the norms of law. This allows one to say that the institute of law cannot be considered the lowest link in the financial law system.

A.N. Kostiukov notes that the financial law system consists of financial law elements that characterize its internal structure and separate it from other branches of law. The financial law system is a structure of legal elements. The structure is relatively independent, stable, autonomous in its functioning and interaction with the external environment (Kostiukov, 2002:27-28). At the same time, the indicated author identifies a grouping of the financial law system elements for a number of reasons. In particular, the horizontal structure of financial law branch is characterized by the following elements. Namely, financial and legal norms, financial and legal institutions that form branches and sub-branches, which are combined into parts of financial law. Along with the horizontal division of the branch, this author identifies the vertical structure, which is based on the financial and legal regulatory material. Based on 
the analysis, A.N. Kostiukov presents a system of financial law, consisting of two parts: general and special. Moreover, the general part includes the following institutions:

- financial law norms,

- financial and legal status of financial law entities,

- financial legal relations,

- legal facts in financial law,

- financial control institution. A special part consists of a sub-branch of budget and tax law, as well as the following sections:

- state (municipal) revenues;

- state (municipal) expenses;

- banking law;

- insurance activity;

- currency regulation;

- monetary circulation and accounting;

— audit activity;

- state credit;

- legal regulation of enterprise finances.

The need to consider the financial law system not only as a horizontal system but also as a vertical system is noted in other studies. (Kostiukov, 2002:54).

N.M. Kazantsev defines a financial law system, consisting of the following sub-branches:

- extraction, processing, turnover of precious metals;

— issuing (banknotes, securities, financial derivatives);

— credit and banking regulation;

- currency regulation;

- accounting;

- tax;

— budget;

- investment;

- insurance;

- financial and appraisal;

- financial markets regulation;

- collection;

- supervisory control (Kazantsev, 2009:33-34).

M.V. Karaseva, considering the formation of a financial law system, concludes that financial and legal regulation has turned into property and legal regulation. The financial law system, according to the indicated author, should be built taking into account two criteria - economic and legal. The economic criterion for the formation of a financial law system is the existing financial system and its cash flows. In turn, the legal classification of financial relations is the legal criterion for systematizing financial law (Karaseva, 2006:97).

D.V. Vinnitskii is critical of the financial law theory's current state of development. He does not recognize financial law as an effectively functioning system ei- 
ther as a branch of law, or as a science, or as an academic discipline (Vinnitskii, 2009:34-36). According to D.V. Vinnitskii, the systematicity should be in the law itself - in principles, concepts, terms, legal structures, and not outside it - in economic relations, scientific doctrines, etc. It is often impossible to detect systemic signs in legal institutions and rules, traditionally included in financial law. E.Yu. Gracheva considers the importance and role of legal norms systematization. She notes that financial law norms systematization can reflect the financial relations' economic content in the legal form. Such a reflection is aimed at effective impact on social processes in the financial sphere (Gracheva, 2009:39-43). E.Yu. Gracheva justifies the presence of sub-branch in the financial law system - financial control. She notes the peculiarity of this branch formation. Namely, a complex structure, as it consists of financial and legal norms that are included in both the general and the special part of financial law.

In turn, A.A. Yalbulganov notes that there is not enough argumentation to classify financial control law as a sub-branch of financial law (Yalbulganov, 2016:182). According to S.V. Zapolskii, the main drawback of financial law is the clear priority of public tasks and interests over private property interests and subjective rights of a person. Noting the lengthy discussion around the financial law system, he emphasizes the following. Namely, "If declaring finance as the sphere of property relations, then the financial law system should exclude the following institutions (which are on a dispositive basis). Such institutions as insurance, savings, bank credit, legal regime of investments, without which finance is generally unthinkable and meaningless" (Zapolskii, 2009:59). Work on the formation of a modern financial law system, in his opinion, should include the creation of a general part:

- common branch principles;

- subjects of financial law;

- general principles of legal liability for violation of financial obligations;

- the legal regime for a financial fund establishment, its fundraising and financing costs;

- general principles of financial procedures regulation;

- the legal basis for accounting and control in the field of finance.

A special part consists of:

- emission law;

— budget law;

- tax law;

- insurance law;

- public debt and state loan;

— savings law (Zapolskii,2008:95-96).

D.V. Vinnitskii considers financial law as a comprehensive legal formation uniting relatively independent legal formations. He considers the active formation (within the system of financial and legal regulation) of two independent legal branches: tax and budget law. He also takes into account exclusion from the financial and legal regulation of the following: 
- banking law,

- insurance law,

- monetary law,

- legal regulation of accounting,

- securities market,

- finances of state and municipal enterprises.

$\mathrm{He}$ assumes that the mentioned active formation of two independent legal branches and exclusion from the financial and legal regulation of the listed elements entail a revision of the traditional approaches to financial law. In general, in the opinion of the indicated author, financial law was transformed into a complex branch, which includes the constitutional-legal institution - the legal foundations of money circulation, as well as independent branches of budget and tax law (Vinnitskii, 2002:30-42).

K.S. Belskii considers in a comprehensive manner the financial law system, as a branch of law, science and university subject. He notes that it is not entirely justified to single out the General and Special Part in its structure. The financial law structure is divided into sub-branches and institutions, and, in his opinion, is presented as follows:

- sub-branches - emission law, budget law, tax law;

- public — banking law, financial control law;

- institutions - state credit, lottery, securities market, finances of enterprises (of all ownership forms), accounting and other institutions (Belskii, 2009:33-40).

The conducted studies substantiate new formations in the financial law system. In particular, E.L. Vasianina considers the obligation of an individual or organization (debtor) to pay money arising in the framework of a financial obligation in order to form public money funds. The obligation arises due to special legal facts provided for by law. The fiscal law covers the latter. A place of fiscal law in the system of financial law is predetermined by the state's management of financial resources and public revenue. At the same time, fiscal law, as a complex sub-branch, is divided into general and special parts. The general part of fiscal law contains the following provisions:

— on profitable financial liabilities,

- principles for regulating relations in the sphere of public money funds,

- general conditions for establishing fiscal levies,

- a mechanism for levies administration,

- monitoring the fulfillment by the debtor of the obligation to form public money funds,

- an institution for defensing the rights of participants in fiscal legal relations.

The special part covers certain types of fiscal levies, the institution of fiscal law of torts. Within the framework of such an institution, there is a legal regime of financial obligations arising from offenses (Vasianina, 2016:12-14). 
Current approaches to the definition of public financial law (as a set of norms and institutions) do not fully reveal its essence. Moreover, the principles of financial law are not considered in the system of elements.

\section{Chapter II}

The principles of public financial law are the legal phenomena that is the subject of research interest, in terms of both theoretical understanding and its practical role in the regulation of public relations in the field of public finance. There are several directions in research - in determining the principles of law as such, the external expression of principles, the correlation of the principles of law and legal norms, the place of principles in the law system. In most literary sources, the principles of law are defined as guidelines (basics) that determine the content and direction of legal regulation. Based on this definition, the principles of law are considered as a synthesizing tool that defines the rulemaking and law enforcement activities, connecting the legal system. Determining the form of existence of the law principles, their diverse nature of expression is noted: from legal theories and concepts to legal orientation. Moreover, they are reflected in the rules of law due to their formulation in the articles of regulatory legal acts. On the one hand, the principles are considered as a core uniting the norms of law and giving a certain preset to norm setting and law enforcement activities. On the other hand, the principles of law do not directly affect the behavior of subjects of law (neither regulatory nor protective). This gives rise to a contradictory idea of the phenomenon of legal principles. On the one hand, they supposedly do not affect the behavior of legal entities. On the other hand, they nevertheless not only predetermine but also directly regulate social relations. E.V. Skurko in detail studies the principles of law and defines the norm as the idea of professional legal consciousness, an attribute of the legal thinking of a lawyer. Principles of law do not establish the law but describe the right to establish one, and mainly through existing legal provisions, etc. (Skurko, 2008:22-29).

V.V. Ershov is the most consistent opponent of considering the principles of law as "fundamental ideas", "basic principles", "provisions". He substantiates that the principles of law are one of the forms of law; principles of law are means of legal regulation of public relations; principles of law - a "road map" for the development of legal norms. Principles of law and rule of law - various regulators of public relations; principles of law — the primary element of the legal system (Ershov, 2018:1518). There is an ambiguous approach to understanding the principles of law in foreign literature as well. According to P. Sandevoir, the principles are proposals, concepts, ideas, which might be:

- either fundamental or simply important,

- based on common sense,

- based on the practice of court decisions,

- sometimes based on one's choice.

The norms, models and goals will consist of principles of law and the legal reasoning will be followed and build by them. Thus, principles play a key and guiding 
role in the development and interpretation of law. Principles must be considered from the essential and operational perspective (Sandevoire, 1994:171-174). J.L. Bergel describes the correlation of principles and legal rules. He describes the essence of law principles as rules, which, in essence, determine the content of any legal system and act as structural elements of the legal order. "Legal rules can be formed and developed only with an eye on the general principles of law" (Bergel, 2000:178).

It is remarkable how the external form of entrenchment of the law principles is considered. J. Pudelka considers this problem on the example of German administrative proceedings. He notes that the principles of administrative proceedings are not always specified in the law; even if they are, they usually do not have detailed regulation or even any definition. They are considered, first, when it comes to interpretation issues. They are taken for granted by administrative bodies and courts (Pudelka, 2018:9-10). As can be seen, the studies are not distinguished by uniformity, which would reveal the essence and role of sectoral principles of law in the regulation of public relations. It should be noted that there is no uniform approach to determining financial law principles in financial and legal literature.

A.A. Podshibiakina defines financial law principles as the legal basis for the creation and orientation of the financial law branch. These principles regulate the most important relations that arise in the process of financial activity of the state and municipalities. The principles are protected from violations by state measures. Podshibiakina concludes that financial law principles are normative formations. The principles have all the features of financial legal norms and are subject to consolidation in the current legislation in the form of legal regulations. (Podshybiakina, 2012:148). Developing this approach, A.A. Pilipenko comes to the following disputable conclusion. The principles have all the features of financial and legal norms and they are characterized by the general three-link structure "hypothesis - disposition — sanction". Moreover, being norms of a high degree of generality, the financial law principles do not always have a clearly defined structure. However, this does not violate the general three-link structure of the principles, because otherwise, they would not be able to participate in the regulatory process. (Pilipenko, 2013:228-235). E.D. Sokolova recognizes the sameness of the principles of financial activity of state and municipalities and the principles of financial law (Sokolova, 2012:7-8).

It is noteworthy that A.I. Zemlinym proposes to abandon the theoretical provisions related to the principles-ideas in financial law and gives the following definition. Principles are fundamental regulatory provisions, objectively determined and enshrined in financial law norms. Principles express the essence, content and features of the regulatory impact on social relations. Social relations are the subject of financial law (Zemlin, 2019:38). As can be seen, there is no uniform approach in the financial and legal literature to determining the essence and role of the law principles in the regulation of public finance. It seems disputable that financial law principles can express normative and regulatory properties only if they are expressed in the norms of branch law. It is even more disputable that they have the same structure: hypothesisdisposition-sanctions. From the point of view of the theory of deontic logic, all norms 
have the same structure and include the following elements: content, patterns, application condition, subject. Without any of these elements, norms do not exist (Ivin, 2016:196-207). In a legal interpretation, any norm includes disposition, hypothesis, and sanction. Moreover, such a structure is inherent only in the norm of law. In the authors' opinion, it is impossible to consider the principles and norms of financial law as identical categories. Since each of these legal phenomena has regulatory properties that are inherent only to them. Therefore, there can be no norm-principles and other forms of combining them with each other that make them look similar. The stable functioning and development of the sphere of modern public finance largely lies not only in the sphere of economic relations, but is also largely influenced by the existing legal regulations in the state. Public finance is not a product of only economic relations, they are directly dependent on the political and legal system of the state. As a result, in the public finances of the state are embodied not only the basic laws of economic relations functioning, but also the basic laws of the legal system of the state. It should be noted that modern legal theory is a kind of pluralistic pie of legal interpretations - from normative to a comprehensive theory of law (Zakhartsev, Salnikov, 2019:108-107). As a result, there are also diverse approaches to understanding the law principles and their role in the regulation of public relations

Based on the analysis, there are the following conclusions. The financial law principles are direct legal regulators of public relations in the field of public finance. Possessing regulatory properties, financial law principles should not be identified with the norms of financial law. Since financial law principles are independent legal means of regulation. The financial law principles, based on their regulatory properties, should be considered as elements of financial law system.

\section{Conclusion}

The modern public financial law system can be defined through the following elements. Namely, the public financial law principles, the rules of public financial law, the institutions of public financial law and their associations. The modern public financial law system is represented by such formations as - budget law, tax law, emission law, financial control law, public banking law. Humanity is at a new stage of its development, which is regarded as the fourth industrial revolution. This stage of development can be called the era of new technologies that are already beginning to influence all spheres of human life. Finance has become an active area of application of these technologies. As a result, new institutions emerge and the existing ones modernize, based on a new technological breakthrough. Money, the core of finance, is already losing its material forms of expression and regulatory properties. Alternative tools appear in the economy that are ready to act as an alternative to money. An alternative to money and money circulation mechanisms will concern the basic tool for regulating economic relations and the financial system of the state as a whole - a monopoly on the issue of banknotes. The transition to a new stage of the industrial revolution encourages states to implement a new policy that aims to transform many public institutions and processes. 
Moreover, the impact of new technological phenomena is on the financial system not only of a particular state, but also on the global finance system. As a result, the construction of public financial law and the legal means of regulating public finances are changing. Value categories influence not only the formation of financial law system elements, but also determine their interaction as legal means of regulating public finances. Legal values are the basis on which legal means of regulation are developed and, with the help of such values, they are implemented.

\section{References / Библиографический список}

Arzumanova, L.L. (2016) Sistema prava denezhnogo obrashcheniya kak podotrasli finansovogo prava Rossiiskoi Federatsii: monografiya [The system of the law of monetary circulation as a subbranch of the financial law of the Russian Federation: Monograph]. E.Yu. Gracheva (ed.). Moscow: Prospect Publ. (in Russian).

Арзуманова Л.Л. Система права денежного обращения как подотрасли финансового права Российской Федерации: монография / отв. ред. Е.Ю. Грачевой. Москва: Проспект, 2016. $126 \mathrm{c}$.

Belikov, E.G. (2016) Finansovoe pravo i ego instituty: problemy sotsial'noi effektivnosti: monografiya [Financial law and its institutions: problems of social efficiency: Monograph]. Doctor of Law, Prof. Pokachalova E.V. (ed.). Moscow: Yurlitinform Publ. (in Russian).

Беликов Е.Г. Финансовое право и его институты: проблемы социальной эффективности: монография / под ред. док. юрид. наук, проф. Е.В. Покачаловой. М.: Юрлитинформ, 2016. 260 с.

Belskii, K.S. (2009) O sisteme prepodavaniya finansovogo prava [On the system of teaching financial law]. State and Law. No. 12. 33-40. (in Russian).

Бельский К.С. О системе преподавания финансового права // Государство и право. 2009. № 12. C. 33-40.

Bergel, J.L. (2000) General theory of law. Translation from French. Danilenko V.I. (ed.). Translation: Churshukova G.V. Moscow: Nota Bene Publ. (in Russian).

Общая теория права. Перевод с французского / Бержель Ж.Л.; Под общ. ред.: Даниленко В.И.; Пер.: Чуршукова Г.В. М.: Nota Bene, 2000. 574 с.

Ershov, V.V. (2018) Legal and individual regulation of public relations: Monograph. Moscow. RGUP Publ. (in Russian).

Ершов В.В. Правовое и индивидуальное регулирование общественных отношений: Монография. М.: РГУП. 2018. 625 с.

Evdokimov, A.Yu. (2013) Aksiologiya finansovogo prava [Axiology of financial law]. Part 1: monograph. Lipetsk - Voronezh: Voronezh Central Scientific Research Institute a branch of the Federal State Budgetary Institution "Russian Energy Company" of the Ministry of Energy of Russia. (in Russian).

Евдокимов А.Ю. Аксиология финансового права. Часть 1: монография. Липецк Воронеж: Воронежский ЦНТИ - филиал ФГБУ «Российская энергетическая компания» Минэнерго России. 2013. 80 с.

Ivin, A.A. (2016) Logika otsenok i norm: filosofskie, metodologicheskie i prikladnye aspekty [The logic of assessments and norms: philosophical, methodological and applied aspects: Monograph]. Moscow: Prospect Publ. (in Russian).

Ивин А.А. Логика оценок и норм: философские, методологические и прикладные аспекты: Монография / А.А. Ивин. Москва: Проспект, 2016. 320 с. 
Gracheva, E.Yu. (2009) Finansovyi kontrol' kak podotrasl' finansovogo prava: ponyatie, vidy. [Financial control as a sub-branch of financial law: concept, types. System of financial law]. Materials of the scientific-practical conference April 27-28, 2009. Odessa. 39-43. (in Russian).

Грачева Е.Ю. Финансовый контроль как подотрасль финансового права: понятие, виды // Система финансового права. Материалы научно-практической конференции, 27-28 апреля 2009 г. Одесса, 2009. С. 39-43.

Karaseva, M.V. (2006) Sovremennye problemy postroeniya sistemy finansovogo prava [Modern problems of building a system of financial law]. Jurisprudence. (3). 94-99. (in Russian).

Карасева М.В. Современные проблемы построения системы финансового права // Правоведение. 2006. № 3. С. 94-99.

Kazantsev, N.M. and oth. (2009) Pravo i finansovyi kontrol' [Law and financial control]. Kazantsev N.M. and others; Institute of Legislation and Comparative Law under the Government of the Russian Federation. Moskow: Eksmo Publ. (in Russian).

Право и финансовый контроль / Н.М. Казанцев и др.; Инст-т законодательства и сравнительного правоведения при Правительстве Российской Федерации. М.: Эксмо, 2009. 336 с.

Kazantsev, N.M. (2009) Instituty finansovogo prava [Institutions of financial law]. Moscow: The Institute of Legislation and Comparative Law. Moscow: Publishing House "Yurisprudentsya". (in Russian).

Институты финансового права / под ред. д. ю. н., профессора Н.М. Казанцева. М.: ИЗиСП. М.: ИД «Юриспруденция», 2009. 512 с.

Kostiukov, A.N. (2002) Diskussionnye voprosy predmeta i sistemy rossiiskogo finansovogo prava: Uchebnoe posobie [Discussion questions of the subject and system of Russian financial law: Textbook]. Omsk. Publishing House of Omsk University. (in Russian).

Костюков А.Н. Дискуссионные вопросы предмета и системы российского финансового права: Учебное пособие. Омск: Изд-во Омск. ун-та, 2002.94 с.

Lagutin, I.B. (ed.) (2017) Regional'noe finansovoe pravo: monografiya [Regional financial law: monograph]. Moscow: Justicinform Publ. (in Russian).

Региональное финансовое право: монография / отв. ред. И.Б. Лагутин. М.: Юстицинформ, 2017. 316 с.

Matveev, P.E. (2017) Aksiologiya: uchebnoe posobie [Axiology: textbook]. In 2 parts. Part 1. Istoriya aksiologii [History of axiology] Matveev P.E.; Vladimir State University named after A.G. and N.G. Stoletovs (VISU). Vladimir: Publishing House of VISU. (in Russian). Матвеев П.Е. Аксиология: учеб. пособие. В 2 ч. Ч. 1. История аксиологии / П. Е. Матвеев; Владим. гос. ун-т им. А.Г. и Н.Г. Столетовых. Владимир: Изд-во ВлГУ, 2017. 176 с.

Mrkývka, Petr (ed.) (2015) System of Financial Law: General Part: Conference Proceedings. $1^{\text {st }}$ ed. Brno: Masaryk University, Faculty of Law Publ.

Mrkývka, Petr (ed.) (2017) The financial law towards challenges of the XXI century: Conference proceedings. $1^{\text {st }}$ ed. editions. Brno: Masaryk University, Faculty of Law Publ.

Pilikin, G.G. (2018) Stanovlenie finansovogo prava Rossii (teoriya i praktika osoboi formy publichnogo prava): monografiya [The Formation of Financial Law of Russia (Theory and Practice of a Special Form of Public Law): Monograph]. Zapolskii S.V. (ed.). Moscow: LTD “Law firm contract” Publ. (in Russian).

Пиликин Г.Г. Становление финансового права России (теория и практика особой формы публичного права): монография // Г.Г. Пиликин; под общ. ред. проф. С.В. Запольского. М.: ООО «Юридическая фирма контракт». 2018. 350 с.

Pudelka, Jörg (2018) Obshchie printsipy administrativnogo proizvodstva [General principles of administrative proceedings]. Ezhegodnik publichnogo prava 2018: Printsipy administra- 
tivnykh protsedur i administrativnogo sudoproizvodstva [Public Law Yearbook 2018: Principles of administrative procedures and administrative proceedings]. Moscow: Infotropic Media Publ. (in Russian).

Пуделька Йорг. Общие принципы административного производства // Ежегодник публичного права 2018: Принципы административных процедур и административного судопроизводства. М.: Инфотропик Медиа, 2018. 374 с.

Pilipenko, A.A. (2013) The meaning and properties of the principles of financial law. Society and Law. 4 (46) 228-235. (in Russian).

Пилипенко А.А. Значение и свойства принципов финансового права // Общество и право. 2013. № 4 (46). С. 228-235.

Podshybiakina, A.A. (2012) The concept of the principles of financial law. Business in law. Journal of Economics and Law. (3), 146-148. (in Russian).

Подиибякина А.А. Понятие принципов финансового права // Бизнес в законе. Экономико-юридический журнал. 2012. № 3. С. 146-148.

Sandevoire, P. (1994) Vvedenie v pravo [Introduction to Law]. Moscow: Intratek-P Publ. (in Russian).

Сандевуар П. Введение в право. М.: Интратэк-Р, 1994. 324 с.

Skurko, E.V. (2008) Printsipy prava: monografiya [Principles of law: monograph]. Moscow: Os'89. (in Russian).

Скурко Е.В. Принципы права: монография. М.: Ось-89, 2008. 192 с.

Sokolova, E.D. (2012) The system of principles of financial law. Financial Law. (8). 7-8. (in Russian).

Соколова Э.Д. Система принципов финансового права // Финансовое право. 2012. № 8. C. 7-8.

Stolovich, L.N. (2009) I. Kant i problema tsennosti [I. Kant and the value problem]. Kant collection 2 (30). Kaliningrad. 20-31. (in Russian).

Столович Л.Н. И.Кант и проблема ценности. Кантовский сборник 2 (30). Калининград. 2009. С. 20-31.

Tsintsadze, N.S. (2013) Conceptual aspects of the axiological theory of law. Bulletin of Tomsk State University, Issue 5 (121). 251-259. (in Russian).

Цинцадзе Н.С. Концептуальные аспекты аксиологической теории права // Вестник ТГУ, выпуск 5 (121), 2013. С. 251-259.

Tsintsadze, N.S. (2014) Classification and hierarchy of legal values in the theory of law. Bulletin of Tomsk State University, issue 2 (130). 189-195. (in Russian).

Цинцадзе Н.С. Классификация и иерархия правовых ценностей в теории права // Вестник ТГУ, выпуск 2 (130), 2014. С. 189-195.

Vasianina, E.L. (2016) Theoretical foundations of the legal regulation of public revenues in the Russian Federation. The work for achieving doctor's degree in legal sciences. Moscow. 12-14. (in Russian).

Васянина Е.Л. Теоретические основы правового регулирования публичных доходов в Российской Федерации. Автореф. дисс. на соиск. учен. степ.. док. юрид. наук. М. 2016. C. 12-14.

Vetiutnev, Yu.Yu. (2013) Aksiologiya pravovoi formy: monografiya [Axiology of legal form: monograph]. Moscow: Yurlitinform Publ. (in Russian).

Ветютнев Ю.Ю. Аксиология правовой формы: монография. М.: Юрлитинформ, 2013. $200 \mathrm{c}$.

Vinnitskii, D.V. (2002) Predmet i sistema finansovogo prava na sovremennom etape [The subject and system of financial law at the present stage]. Jurisprudence. 5 (244). 30-42. (in Russian). 
Винницкий Д.В. Предмет и система финансового права на современном этапе // Правоведение. 2002. № 5 (244). С. 30-42.

Vinnitskii, D.V. (2009) Finansovoe pravo: khaos ili sistema? // Financial law: chaos or system? System of financial law. Materials of the scientific-practical conference April 27-28, 2009. Odessa. 34-36. (in Russian).

Винницкий Д.В. Финансовое право: хаос или система? // Система финансового права. Материалы научно-практической конференции 27-28 апреля 2009. Одесса. 2009. C. 34-36.

Yalbulganov, A.A. (2016) Predmet i sistema finansovogo prava: Monografiya. Subject and system of financial law: Monograph. Moscow: Public law research institute Publ. (in Russian). Ялбулганов А.А. Предмет и система финансового права: Монография. М.: ИППИ, 2016. 192 c.

Zakhartsev, S.I., Salnikov, V.P. (2019) Filosofiya i yuridicheskaya nauka [Philosophy and legal science: Monograph]. Moscow: Yurlitinform Publ. (in Russian).

Захариев С.И., Сальников В.П. Философия и юридическая наука: Монография. М.: Юрлитинформ, 2019. 424 с.

Zapolskii, S.V. (2009) K voprosu o sushchnosti finansovogo prava [On the issue of the essence of financial law. System of financial law]. Materials of the scientific-practical conference. April 27-28, 2009. Odessa. (in Russian).

Запольский C.B. К вопросу о сущности финансового права // Система финансового права. Материалы научно-практической конференции 27-28 апреля 2009 г. Одесса, 2009. C. 59.

Zapolskii, S.V. (2008) Diskussionnye voprosy teorii finansovogo prava: monografiya [Discussion questions of the theory of financial law: monograph]. Moscow. RAP, EKSMO Publ. (in Russian).

Запольский С.В. Дискуссионные вопросы теории финансового права: монография. М.: РАП, ЭКСМО. 2008. 160 c.

Zemlin, A.I. (2019) Financial Law of the Russian Federation: a textbook for undergraduates. Zemlin A.I., Zemlina O.M., Olkhovskaia N.P., Zemlina A.I. (eds.). Moscow: Publishing house Yurait Publ. (in Russian).

Землин А.И. Финансовое право Российской Федерации: учебник для бакалавриата и специалитета / А.И. Землин, О.М. Землина, Н.П. Ольховская; под общ. ред. А.И. Землина. М.: Издательство Юрайт, 2019. 301 с.

\section{About author:}

Imeda A. Tsindeliani - Candidate of Law, Associate Professor, Head of the Department of Financial Law, Russian State University of Justice

ORCID ID: 0000-0003-3975-2958

e-mail: imeda_pravo@mail.ru

\section{For citation:}

Tsindeliani, I.A. (2020) Axiological aspects of the financial law system. RUDN Journal of Law. 24(1), pp. 82-97. DOI: 10.22363/2313-2337-2020-24-1-82-97.

Article received October 11, 2019

Article accepted December 25, 2019 


\title{
АКСИОЛОГИЧЕСКИЕ АСПЕКТЫ СИСТЕМЫ ФИНАНСОВОГО ПРАВА
}

\author{
И.А. Цинделиани \\ Российский государственный университет правосудия \\ 117418, Москва, Россия, ул. Новочеремушкинская, д. 69
}

Правовая аксиология, как научное направление, позволяет рассмотреть правовую систему государства в целом, так и ее отдельные элементы с точки зрения ценностных фундаментов, существующих в обществе и у каждого индивидуума в отдельности. Рассмотрение элементов правовой системы государства через ценностные категории позволяет определить взаимосвязь и взаимообусловленность всех элементов правовой системы. Особо необходимо отметить влияние ценностных категорий и на формирование системы отдельных отраслей права, в том числе и финансового права России. Ценностные категории влияют не только на формирование элементов системы финансового права, но и предопределяют их взаимодействие как правовых средств регулирования публичных финансов. Элементами системы финансового права, как отрасли права, являются принципы финансового права, нормы финансового права и их отдельные формы группировки - институты и подотрасли финансового права. Принципы финансового права по своей природе являются непосредственными правовыми регуляторами общественных отношений в сфере публичных финансов. Обладая регулирующими свойствами, принципы финансового права не должны отождествляться с нормами финансового права, поскольку являются самостоятельными правовыми средствами регулирования. Принципы финансового права, исходя из их регулирующих свойств, должны рассматриваться как элементы системы финансового права.

Ключевые слова: аксиология права, финансовое право, принципы финансового права, нормы финансового права, институты финансового права, бюджетное право, налоговое право, банковские право, эмиссионное право, финансово-контрольное право

\section{Краткое содержание статьи}

Ценности, сформированные обществом, несомненно, предопределяют эволюцию всех социальных институтов, в том числе и права. Ценностная ориентация имеет значительное влияние на право как особый феномен. Значительное влияние ценностных фундаментов оказывается на систематизацию прав в целом, так и ее отдельных элементов. Модели правового регулирования тех или иных общественных отношений предопределяются аксиологическими свойствами имеющихся средств правового регулирования. Для достижения максимального социального эффекта регулирования общественных отношений имеющиеся средства правового регулирования находятся во взаимосвязи с ценностными фундаментами, выработанными обществом. В основе любой модели правового регулирования лежат социальные ценности, которые посредством средств правового регулирования получают нормативное закрепление и трансформируются в правовые ценности. Правовая аксиология, как научное направление, позволяет рассмотреть как правовую систему государства в целом, так и ее отдельные элементы с точки зрения ценностных фундаментов, существу- 
ющих в обществе и у каждого индивидуума в отдельности. Рассмотрение элементов правовой системы государства через ценностные категории позволяет определить взаимосвязь и взаимообусловленность всех элементов правовой системы. Особо необходимо отметить влияние ценностных категорий и на формирование системы отдельных отраслей права, в том числе и финансового права России. Ценностные категории влияют не только на формирование элементов системы публичного финансового права, но и предопределяют их взаимодействие как правовых средств регулирования публичных финансов. Правовая аксиология оказывает значительное влияние на сферу публичных финансов и на выбор правовых инструментов, посредством которых достигается баланс интересов между публично-правыми образованиями и частными субъектами. Выработка такого баланса и влияние ценностных фундаментов на выбор средств правового регулирования наиболее ярко проявляется на примере систематизации модели правового регулирования сферы публичных финансов. Наиболее ярко это можно увидеть на структуре конкретных отраслей права и, прежде всего, финансового права. Правовая аксиология влияет на каждый из элементов системы финансового права, обеспечивает достижение оптимального правового результата. При этом необходимо отметить, что публичные финансы, играющие значительную роль в функционировании экономики общества, сегодня находятся на этапе трансформации. Обусловлено это новым технологическим этапом развития человеческого общества и формированием цифровой экономики. Финансовая система государства не осталась в стороне от технологической революции и интегрирует в себя все новые и новые инструменты, позволяющие усовершенствовать финансовую систему государства, так и важнейший ее сегмент, как публичные финансы.

Система финансового права является базовой категорией, раскрывающей построение отрасли права. Традиционно в большинстве исследований система финансового права представлена состоящей из общей и особенной частей, институтов и подотраслей. Имеющиеся современные подходы к определению системы финансового права, как совокупности норм и институтов, не в полной мере раскрывают содержание категории системы публичного финансового права. При этом в системном ряде элементов не рассматриваются принципы финансового права. Принципы финансового права представляется необходимым рассматривать как самостоятельный элемент правового регулирования. Соответственно, в системе финансового права как ее важнейший элемент необходимо рассматривать принципы публичного финансового права. Отсутствует единообразный подход к природе правовых принципов и их роли в регулировании общественных отношений. Не имеется единообразного подхода к определению природы принципов финансового права и их роли регулирования публичных финансов. Допускается ошибочное отождествление принципов и норм финансового права. Значительное влияние оказывает правовая аксиология на формирование системы финансового права России, по- 
скольку именно отражение в средствах правового регулирования позволяет достичь эффективного регулятивного эффекта сферы публичных финансов.

Современную систему финансового права можно определить через следующие элементы - принципы финансового права, нормы финансового права, институты финансового права и их объединения. Современная система финансового права представлена такими образованиями, как бюджетное право, налоговое право, эмиссионное право, финансово-контрольное право, публичное банковское право и др.

Ценностные категории играют важную роль не только при разрешении конфликтов при отраслевом или межотраслевом регулировании. Категория ценности играет роль куда более широкую, чем разрешение конфликтов. Ценности, которые выработаны и утверждены в обществе и различных организационных формах существования человеческого социума, непосредственно влияют на формирование правовых средств регулирования общественных отношений. Правовые средства как инструментарий, который обеспечивает упорядочивание общественных отношений, формируется на определенных ценностях. Соответственно, ценности являются той базой, на основе которой вырабатываются правовые средства регулирования, и с оглядкой на такие ценности они реализуются.

\section{Об авторе:}

Цинделиани Имеда Анатольевич - заведующий кафедрой финансового права Российского государственного университета правосудия, профессор кафедры, кандидат юридических наук, доцент

ORCID ID: 0000-0003-3975-2958

e-mail: imeda_pravo@mail.ru

\section{Для цитирования:}

Цинделиани И.А. Аксиологические аспекты системы финансового права // Вестник Российского университета дружбы народов. Серия: Юридические науки. 2020. Т. 24. № 1. C. 82-97. DOI: 10.22363/2313-2337-2020-24-1-82-97.

Дата поступления в редакцию: 11 октября 2019 г. Дата принятия к печати: 25 декабря 2019 г. 